\title{
PENGEMBANGAN BAHAN AJAR KEWIRAUSAHAAN BERBASIS KONTEKSTUAL PADA MATA PELAJARAN BISNIS MANAJEMEN
}

\author{
Khoirun Nikmah ${ }^{1}$, R. Mursid ${ }^{2}$, Samsidar Tanjung ${ }^{3}$ \\ ${ }^{1}$ SMK BM APIPSU Medan, ${ }^{2,3}$ Pascasarjana Universitas Negeri Medan \\ khoirunsibarani@gmail.com ${ }^{l}$; mursid.tp@gmail.com ${ }^{2}$
}

\begin{abstract}
Abstrak: penelitian ini bertujuan untuk: (1) mengembangkan bahan ajar kewirausahaan berbasis kontekstual pada siswa, (2) menggunakan bahan ajar kewirausahaan berbasis kontekstual dalam pembelajaran layak digunakan pada siswa. Jenis penelitian ini adalah penelitian pengembangan yang menggunakan model pengembangan produk Borg and Gall yang dipadu dengan model desain pembelajaran Dick and Carey. Metode penelitian terdiri dari tujuh langkah yaitu sebagai berikut : (1) analisis kebutuhan, (2) mengembangkan produk awal, (3) validasi ahli dan revisi, (4) uji coba perorangan, (5) uji coba kelompok kecil, (6) uji coba lapangan terbatas, dan (7) produk akhir. Hasil penelitian menunjukkan : (1) uji ahli materi berada pada kualifikasi sangat baik (90,58\%), (2) uji ahli desain pembelajaran berada pada kualifikasi sangat baik (82,89), (3) uji ahli media pembelajaran berada pada kualifikasi sangat baik (83,55), (4) uji coba perorangan berada pada kualifikasi sangat baik (92,94), (5) uji coba kelompok kecil berada pada kualifikasi sangat baik (95,72), dan (6) uji coba lapangan terbatas berada pada kualifikasi sangat baik(95,10). Dengan demikian, pengembangan bahan ajar berbasis kontekstual layak digunakan dalam pembelajaran kewirausahaan.
\end{abstract}

Kata Kunci: bahan ajar kewirausahaan, kontekstual, siswa Sekolah Menengah Kejuruan

This study aims to: (1) develope contextual based instructional material in entrepreneurship for students, (2) use contextual based instructional material in entrepreneurship in effective instruction which is used by students. The type of this research is the research and development that used the product development model of Borg and Gall and combined with instructional design model of Dick and Carey. The research method consists of seven steps as follows: (1) need assessment, (2) to develop the initial product, (3) the expert validation and revision, (4) individual trial, (5) small group trial, (6) a limited field trial, and (7) final product. The result of this research showed: (1) the test of subject matter experts is at the excellent qualification (88.23\%), (2) the test of the instructional design experts is at the excellent qualification (82.89\%), (3) the test of the instructional media experts is at the excellent qualification (83.55), (4) the individual trial is at the excellent qualification (92.94\%), (5) the small groups trial is at the excellent qualification (95.72\%), and (6) the limited field trial is at the excellent qualification (95.10\%). Thus, the development of contextual based instructional material is effective to be used in enterpreneurship instruction.

Keywords: instructional material in entrepreneurship, contextual, student of Vocational High Scool

\section{PENDAHULUAN}

Manusia yang berkualitas adalah manusia yang dapat mengikuti perkembangan zaman dan ilmu teknologi. Perkembangan zaman dan ilmu teknologi memberikan dampak positif terhadap dunia pendidikan. Karena pendidikan merupakan faktor utama dalam pembentukan karakter siswa sehingga siswa dapat mengembangkan potensi dan keterampilan yang dimilikinya.

Pendidikan adalah usaha sadar dan sistematis yang dilakukan oleh orang-orang yang diserahi tanggung jawab untuk mempengaruhi siswa sehingga mempunyai sifat dan tabiat sesuai dengan cita-cita pendidikan. Menurut Daryanto (2012:1) pendidikan merupakan pendewasaan siswa agar dapat mengembangkan bakat, potensi, dan keterampilan yang dimiliki dalam menjalani kehidupan. Pernyataan di atas sesuai dengan tujuan pendidikan SMK di Indonesia yaitu untuk "meningkatkan kecerdasan, pengetahuan, kepribadian, akhlak mulia serta keterampilan untuk hidup mandiri dan mengikuti pendidikan lanjut sesuai dengan kejuruannya" (Permendiknas nomor 22 tahun 2006).

Dari tujuan yang akan dicapai melalui pendidikan kejuruan tersebut diharapkan lulusan SMK dipersiapkan untuk memasuki dunia kerja, yang terstruktur di dalam industri, dan juga pada sektor informal yang membutuhkan kemandirian kerja (PP nomor 29 
tahun 1990). Oleh karena itu, kurikulum SMK menekankan pada pemberian bekal kemampuan yang sesuai dan berorientasi pada kebutuhan pemakai tamatan (demand driven).

Untuk mewujudkan hal tersebut, sejak tahun 2006 melalui KTSP, guru diberi keluasan untuk mendesain pembelajaran baik dari segi materi, metode, media, sistem evaluasi dan strategi atau model pembelajaran yang selaras dengan kondisi perkembangan kebutuhan dunia industri dan dunia usaha.

Melalui KTSP, SMK BM APIPSU Medan sebagai lembaga pendidikan telah berupaya meningkatkan mutu pendidikan disekolah melalui perbaikan proses pembelajaran, peningkatan kompetensi guru, mengaktifkan MGMP (Musyawarah Guru Mata Pelajaran), kerjasama dengan dunia industri serta perbaikan sarana dan prasarana. Berbagai konsep dan wawasan baru tentang pembelajaran di sekolah terus muncul dan berkembang seiring pesatnya perkembangan ilmu pengetahuan dan teknologi. Guru sebagai pendidik menduduki posisi yang sangat penting dalam rangka pengembangan sumber daya manusia, dituntut untuk terus mengikuti berkembangnya konsep-konsep baru dalam pembelajaran agar hasil belajar siswa lebih optimal.

Namun untuk mengikuti konsep dan wawasan baru tentang pembelajaran masih banyak ditemukan kendala dilapangan. Dari hasil observasi yang dilakukan di SMK BM APIPSU Medan, kurang berhasilnya pembelajaran kewirausahaan karena rendahnya tingkat penguasaan materi kewirausahaan. Hal ini disebabkan karena bahan ajar yang digunakan guru adalah bahan ajar berupa LKS yang telah disediakan di sekolah, sehingga guru belum terbiasa membuat atau mendesain sendiri bahan ajar yang digunakan, selain itu masih ada beberapa hal yang membuat nilai siswa rendah, yaitu: (1) sulit memahami serta menerapkan materi pembelajaran dalam kehidupan seharihari, (2) materi pada buku teks yang digunakan tidak memberikan contoh dan gambaran yang jelas kepada siswa, (3) buku teks yang digunakan siswa kurang menarik sehingga menyebabkan siswa kurang tertarik dalam mempelajari materi, dan (4) buku-buku yang dipakai kurang memadai yang dapat menunjang keberhasilan penguasaan materi serta penerapannya dalam kewirausahaan.

Buku teks kewirausahaan yang digunakan sekarang belum tertata dengan baik, karena cenderung hanya memperhatikan struktur perkembangan kognitif anak. Ditemukan dalam buku kewirausahaan hanya membahas materi kewirausahaannya saja tanpa mengamati lingkungan sekitarnya, serta membosankan karena terlalu banyak teori tanpa menerapkannya.

Padahal dalam SMK, kewirausahaan merupakan mata pelajaran wajib di SMK sesuai dengan tujuan SMK yaitu menyiapkan lulusan yang siap kerja dan siap terjun kemasyarakat dan dengan mempelajari mata pelajaran kewirausahaan lulusan SMK diharapkan tidak hanya menjadi pencari kerja, tetapi bisa menjadi pencipta pekerjaan dengan cara berwirausaha. (Frank, 2005).

Untuk mengatasi hal tersebut dibutuhkan bahan ajar kewirausahaan berbasis kontekstual. Menurut Dick and Carey (2005:241), mengungkapkanbahan ajar merupakan seperangkat materi, substansi pelajaran (teaching material) yang disusun secara sistematis, menampilkan sosok utuh dari kompetensi yang akan dikuasai oleh siswa dalam kegiatan pembelajaran. Sependapat dengan Pannen (2001) mengungkapkan bahwa bahan ajar merupakan bahan-bahan atau materi pelajaran yang disusun secara sistematis, yang digunakan guru dan siswa dalam proses pembelajaran. Jadi, dapat disimpulkan bahan ajar adalah seperangkat materi pembelajaran berupa media atau perangkat lunak yang disusun secara logis dan sistematis untuk memudahkan guru dan siswa dalam mencapai standar kompetensi yang diinginkan.

Dalam penyusunan bahan ajar, ada beberapa hal yang harus diperhatikan, yaitu kaidah penyusunan bahan ajar, komponen dalam bahan ajar, prinsip penyusunan bahan ajar, dan peranan bahan ajar dalam pembelajaran. Menurut Widodo dan Jasmadi (2008:42), kaidah dalam penyusunan bahan ajar adalah : (1) bahan ajar harus disesuaikan dengan siswa yang sedang mengikuti proses belajar mengajar, (2) bahan ajar diharapkan mampu mengubah tingkah laku siswa, (3) bahan ajar yang dikembangkan harus sesuai dengan kebutuhan dan karakteristik siswa, (4) bahan ajar mencakup tujuan kegiatan pembelajaran yang spesifik, (5) guna mendukung ketercapaian, bahan ajar harus memuat materi pembelajaran secara rinci, layak untuk kegiatan maupun latihan, (6) terdapat evaluasi sebagai umpan balik atau alat untuk mengukur tingkat keberhasilan siswa. selain 
kaidah, komponen bahan ajar juga harus diperhatikan, yaitu pendahuluan, kegiatan belajar, latihan, rambu-rambu jawaban latihan, rangkuman, tes formatif, dan kunci jawaban tes formatif (Sungkono, dkk, 2003). Menurut Sukiman (2011:17) tujuan penyusunan bahan ajar adalah: (a) membantu siswa dalam mempelajari sesuatu, (b) menyediakan berbagai jenis pilihan bahan ajar, (c) memudahkan guru dalam melaksanakan pembelajaran, (4) agar kegiatan pembelajaran lebih menarik. Dan prinsip penyusunan bahan ajar menurut Sudrajat (2008:1) dalam menyusun bahan ajar terdapat prinsip-prinsip dalam pemilihan materi pembelajaran meliputi: (a) prinsip relevansi, (b) konsistensi, dan (c) kecukupan. Prinsip relevansi artinya materi pembelajaran hendaknya relevan memiliki keterkaitan dengan pencapaian standar kompetensi dan kompetensi dasar.pada standar kompetensi mengaktualisasi sikap dan perilaku wirausaha. Prinsip konsistensi artinya adanya keterkaitan antara bahan ajar dengan kompetensi dasar yang harus dikuasai siswa. Prinsip kecukupan artinya materi yang diajarkan hendaknya cukup memadai dalam membantu siswa menguasai kompetensi dasar yang diajarkan.

Menurut Belawati (2003:15) peranan bahan ajar dalam pembelajaran antara lain: (1) menghemat waktu guru dalam mengajar, (2) mengubah peran guru dari seorang pengajar menjadi seorang fasilitator, (3) meningkatkan proses pembelajaran menjadi lebih efektif dan interaktif, (4) siswa dapat belajar tanpa tanpa harus ada guru atau teman siswa yang lain, (5) peserta didik dapat belajar kapan saja dan dimana saja ia kehendaki, (6) siswa dapat belajar sesuai dengan kecepatannya sendiri, (7) siswa dapat belajar menurut urutan yang dipilihnya sendiri, dan (8) membantu potensi siswa untuk belajar mandiri.

Bahan ajar juga memiliki posisi amat penting dalam pembelajaran yakni sebagai representasi (wakil) dari penjelasan guru didepan kelas. Menurut Prastowo (2011:24-25) dibedakan atas: (1) bagi guru antara lain menghemat waktu, merubah guru menjadi fasilitator, mengektifkan pembelajaran sebagai pedoman dan alat evaluasi, (2) bagi siswa dapat digunakan kapan dan dimanapun, belajar sesuai kecepatan, menggali potensi siswa, dan pedoman untuk mengarahkan aktivitas dalam pembelajaran, (3) bagi strategi pembelajaran bahan ajar dapat berfungsi sebagai pembelajaran klasikal, individual dan kelompok.

Menurut Milfayetty, dkk (2011:84) pembelajaran kontekstual merupakan konsep yang menghubungkan antara materi pelajaran dengan situasi siswa dan mendorong siswa untuk membuat hubungan antara pengetahuan yang dimilikinya dengan melibatkan tujuh komponen utama pembelajaran kontekstual yakni konstruktivisme, bertanya, inquiry, masyarakat belajar, pemodelan dan penilaian autentik. Sependapat dengan Sagala (2005:87) menyatakan bahwa model pembelajaran kontekstual (Contextual Teaching and Learning) yang disingkat dengan CTL merupakan konsep belajar yang membantu guru mengaitkan antara materi yang diajarkan dengan sirtuasi dunia nyata siswa dan mendorong siswa membuat hubungan antara pengetahuan yang dimiliknya dengan penerapannya dalam kehidupan mereka sebagai anggota keluarga dan masyarakat. Jadi dapat disimpulkan bahwa kontekstual adalah menghubungkan materi yang dipelajari dengan kehidupan nyata siswa. sependapat juga dengan Hudson dan Whisler (2006:58) pembelajaran kontekstual adalah membantu guru menghubungkan konten materi dengan dunia nyata, situasi, dan memotivasi siswa untuk membuat koneksi antara pengetahuan dan aplikasinya terhadap kehidupan mereka sebagai anggota keluarga, warga negara, dan pekerja, dan terlibat dalam kerja keras yang dibutuhkan dalam pembelajaran.

Dengan mengembangkan bahan ajar berbasis kontekstual siswa dapat diarahkan untuk menjelaskan fenomena nyata dan menyelesaikan permasalahan dalam kehidupan sehari-hari dengan dibekali penguasaan konsep yang mereka bangun sendiri lewat materi yang dikaitkan dengan lingkungan sendiri. Seperti pada mata materi mengidentifikasi sikap dan perilaku wirausaha, dimana siswa diharapkan mampu mengidentifikasi sikap dan perilaku seorang wirausaha, faktor-faktor yang mempengaruhi keberhasilan, kegagalan wirausaha serta keterampilan yang harus dimiliki seorang wirausaha, dan bagaimana cara wirausaha menyikapi permasalahan dalam usahanya tersebut dengan cara mengamati lingkungannya, siswa dituntut bukan hanya memahami materi tetapi menerapkan serta dapat menghubungkan materi yang dipelajari dengan lingkungannya. 
Rumusan masalah dalam penelitian dan pengembangan ini adalah Apakah pengembangan bahan ajar kewirausahaan berbasis kontekstual dalam pembelajaran layak digunakan pada siswa kelas X AP SMK BM APIPSU Medan?

\section{METODE PENELITIAN}

Penelitian ini dilaksanakan di SMK BM APIPSU Medan, jalan Jambi No. 25 Medan, pada siswa kelas $X$ AP dan $X$ AK mata pelajaran kewirausahaan pada standar kompetensi mengaktualisasi sikap dan perilaku wirausaha. Penelitian dan pengembangan ini merujuk pada langkah-langkah penelitian pengembangan model Borg and Gall, pengembangan bahan ajar merujuk pada Dick and Carey. Langkah-langkah yang dilakukan dalam pengembangan Borg and Gall adalah: (1) tahap analisis kebutuhan, (2) tahap perancangan bahan ajar, dan (3) tahap uji coba (validasi). Pada tahap analisis, kegiatan yang dilakukan berupa analisis beberapa aspek pembelajaran yang akan dicapai sesuai dengan standar kompetensi. Analisis aspek tersebut menjadi tiga tahap, yaitu: melakuakn studi, pendahuluan, dan mengidentifikasi kebutuhan analisis pembelajaran.

Bahan ajar yang akan dikembangkan adalah untuk siswa kelas X SMK semester ganjil dengan menggunakan kurikulum KTSP dengan standar kompetensi mengaktualisasi sikap dan perilaku wirausaha. Siswa diharapkan mampu mengidentifikasi serta menerapkan sikap dan perilaku wirausaha.

Adapun tahapan dari desain uji coba pengembangan bahan ajar dalam penelitian ini adalah sebagai berikut:

a. Validasi ahli materi pembelajaran,

Dimana:

$$
\mathrm{X}=\frac{R}{N} \times 100 \%
$$

$\mathrm{X}=$ nilai yang diharapkan (dicari)

$\mathrm{R}=$ jumlah skor dari item atau skor yang benar

$\mathrm{N}=$ skor mmaksimum dari tes tersebut

Dengan kriteria skor persentase penilaian menurut Arikunto (1998: 246) seperti yang tertulis pada tabel 1. Berikut ini.

Tabel 1. Kriteria penilaian Bahan Ajar

\begin{tabular}{llc}
\hline No & \multicolumn{1}{c}{ Kriteria } & Rentang Skor \\
\hline 1 & Sangat baik & $75 \% \leq X \leq 100 \%$ \\
\hline 2 & Baik & $55 \% \leq X<75 \%$ \\
\hline 3 & Kurang baik & $40 \% \leq X<55 \%$ \\
\hline 4 & Tidak baik & $X<40 \%$ \\
\hline
\end{tabular}

b. Validasi ahli desain pembelajaran,

c. Validasi ahli media pembelajaran,

d. Revisi pengembangan (tahap I), berdasarkan penilaian yang berupa masukan, kritik atau saran dari tiga ahli, materi desain dan media,

e. Uji coba perorangan oleh tiga siswa (uji coba satu-satu),

f. Uji coba sembilan orang siswa (uji coba kelompok kecil),

g. Revisi tahap II, berdasarkan penilaian yang berupa masukan, kritik atau saran dari uji coba perorangan dan kelompok kecil.

h. Uji coba lapangan terhadap 24 orang siswa kelas X AP 1 tentang penilaian mengenai

i. Revisi tahap III, berdasarkan penilaian yang berupa masukan, kritik atau saran dari uji coba lapangan

j. Revisi produk akhir untuk penyempurnaan, dan dilanjutkan dengan uji efektifitas produk dalam proses pembelajaran.

Uji coba dalam penelitian ini dilakukan dengan membagikan angket penilaian. Angket diberikan kepada siswa untuk mengetahui penilaian siswa terhadap bahan ajar yang dikembangkan. Angket penilaian dibuat dalam skala 1 sampai 4 dengan kriteria sebagai berikut:

1) $1=$ jika sangat baik/sangat cocok/sangat lengkap/sangat memadai

2) $2=$ jika baik/cocok/lengkap/memadai

3) $3=$ jika kurang baik/kurang cocok/kurang lengkap/kurang memadai

4) $4=$ jika tidak baik/tidak cocok/tidak lengkap/tidak memadai

Kriteria penilaian validasi ahli bahan ajar menggunakan skala Likert yang dianalisis secara deskriptif peresentase dengan rumus sebagai berikut. daya tarik dan kelayakan produk, 


\section{HASIL DAN PEMBAHASAN}

Hasil validasi berupa skor penilaian terhadap komponen-komponen bahan ajar kewirausahaan berbasis kontekstual pada kualitas materi pembelajaran dapat dilihat pada tabel 2 .

Tabel 2. Skor Penilaian Ahli Materi Pembelajaran

\begin{tabular}{clccccc}
\hline No & \multicolumn{1}{c}{ Aspek } & \multicolumn{2}{c}{ Responden } & Jlh. & Rata-rata & Kriteria \\
\cline { 3 - 4 } & & $\mathbf{1}$ & $\mathbf{2}$ & skor & & \\
\hline 1 & Aspek kelayakan isi & 21 & 21 & 42 & $87,50 \%$ & Sangat baik \\
\hline 2 & Aspek kelayakan penyajian & 21 & 22 & 43 & $89.58 \%$ & Sangat baik \\
\hline 3 & Aspek kebahasaan & 11 & 11 & 22 & $91,66 \%$ & Sangat Baik \\
\hline 4 & Aspek kegrafikan & 6 & 7 & 22 & $91,66 \%$ & Sangat Baik \\
\hline & Jumlah rata-rata & & & 120 & $88,23 \%$ & Sangat Baik \\
\hline
\end{tabular}

Hasil validasi berupa skor komponen bahan ajar kewirausahaan berbasis kontekstual. Menurut ahli desain pembelajaran kualitas bahan ajar yang dikembangkan sudah baik dan layak diujicobakan.

Tabel 3. Skor Penilaian Ahli Desain Pembelajaran

\begin{tabular}{clccccc}
\hline No & \multicolumn{1}{c}{ Aspek } & \multicolumn{2}{c}{ Responden } & \multirow{2}{*}{$\begin{array}{c}\text { Jlh. } \\
\text { skor }\end{array}$} & Rata-rata & Kriteria \\
\cline { 3 - 4 } & & $\mathbf{1}$ & $\mathbf{2}$ & & \\
\hline 1 & Aspek kelayakan isi & 13 & 15 & 28 & $87,50 \%$ & Sangat baik \\
\hline 2 & Aspek kelayakan penyajian & 29 & 34 & 63 & $78,75 \%$ & Sangat baik \\
\hline 3 & Aspek kegrafikan & 16 & 19 & 35 & $87,50 \%$ & Sangat Baik \\
\hline$\quad$ Jumlah rata-rata & & & 126 & $82,89 \%$ & Sangat Baik \\
\hline
\end{tabular}

Validasi ahli media pembelajaran dilakukan oleh dua orang ahli media pembelajaran. Ahli media pembelajaranmemvalidasi produk aspek-aspek media pembelajaran diantaranya pada aspek kelayakan isi, kelayakan penyajian, dan kegrafikan. Hasil validasi berupa skor penialian komponen bahan ajar kewirausahaan berbasis kontekstual.

Tabel 4. Skor Penilaian Ahli Media Pembelajaran

\begin{tabular}{clccccc}
\hline No & \multicolumn{1}{c}{ Aspek } & \multicolumn{2}{c}{ Responden } & \multirow{2}{*}{ Jlh. } & Rata-rata & Kriteria \\
\cline { 3 - 4 } & & $\mathbf{1}$ & $\mathbf{2}$ & skor & & \\
\hline 1 & Aspek kelayakan isi & 11 & 11 & 22 & $91,60 \%$ & Sangat baik \\
\hline 2 & Aspek kelayakan penyajian & 34 & 34 & 68 & $85,00 \%$ & Sangat baik \\
\hline 3 & Aspek kegrafikan & 18 & 19 & 37 & $77,08 \%$ & Sangat Baik \\
\hline$\quad$ Jumlah rata-rata & & & 127 & $83,55 \%$ & Sangat Baik \\
\hline
\end{tabular}

Penilaian dan masukan uji coba ini adalah tentang penyajian produk pembelajaran meliputi kelayakan isi, kelayakan penyajian, kelayakan bahasa, dan pemilihan gambar.

Tabel 5. Data Hasil Angket Uji Coba Perorangan

\begin{tabular}{clcccccc}
\hline No & \multirow{2}{*}{ Aspek } & \multicolumn{3}{c}{ Responden } & Jlh. & Rata-rata & \multirow{2}{*}{ Kriteria } \\
\cline { 3 - 6 } & & $\mathbf{1}$ & $\mathbf{2}$ & $\mathbf{3}$ & Skor & & \\
\hline 1 & Aspek kelayakan isi & 18 & 18 & 20 & 56 & $93,33 \%$ & Sangat baik \\
\hline 2 & Aspek kelayakan penyajian & 15 & 13 & 14 & 42 & $87,50 \%$ & Sangat baik \\
\hline 3 & Aspek kebahasaan & 8 & 8 & 7 & 23 & $95,83 \%$ & Sangat Baik \\
\hline 4 & Aspek kegrafikan & 8 & 8 & 8 & 24 & $100 \%$ & Sangat Baik \\
\hline & Jumlah rata-rata & & & & 120 & $92,94 \%$ & Sangat Baik \\
\hline
\end{tabular}

Uji coba kelompok kecil ini digunakan sebagai pengalaman awal sebelum produk diujicobakan kelapangan. Data hasil uji coba kelompok kecil dapat dilihat pada tabel 6 . 
Tabel 6. Data Hasil Angket Uji Coba Kelompok Kecil

\begin{tabular}{|c|c|c|c|c|c|c|c|}
\hline \multirow[t]{2}{*}{ No } & \multirow[t]{2}{*}{ Indikator/ Pernyataan } & \multicolumn{4}{|c|}{ Skor } & \multirow{2}{*}{$\begin{array}{c}\text { Rata- } \\
\text { rata }\end{array}$} & \multirow[t]{2}{*}{ Kriteria } \\
\hline & & 1 & 2 & 3 & 4 & & \\
\hline & I. ASPEK KELAYAKAN ISI & & & 170 & & $94,44 \%$ & Sangat baik \\
\hline 1. & Kesesuaian materi & & & 1 & 8 & $97,22 \%$ & Sangat baik \\
\hline 2. & $\begin{array}{l}\text { Kejelasan petunjuk dalam } \\
\text { pembelajaran }\end{array}$ & & & & 9 & $100 \%$ & Sangat baik \\
\hline 3. & Kemudahan memahami kalimat teks & & & 4 & 5 & $83,33 \%$ & Sangat baik \\
\hline 4. & Ketepatan urutam materi & & & 2 & 7 & $91,66 \%$ & Sangat baik \\
\hline 5. & $\begin{array}{l}\text { Keterlibatan dan peran siswa dalam } \\
\text { aktifitas belajar }\end{array}$ & & & 3 & 6 & $91,66 \%$ & Sangat baik \\
\hline & $\begin{array}{l}\text { II. ASPEK KELAYAKAN } \\
\text { PENYAJIAN }\end{array}$ & & & 141 & & $97,91 \%$ & Sangat baik \\
\hline 6. & Kualitas gambar & & & & 9 & $100 \%$ & Sangat baik \\
\hline 7. & Komposisi warna & & & & 9 & $83,33 \%$ & Sangat baik \\
\hline 8. & Kemenarikan isi cerita & & & 1 & 8 & $75,00 \%$ & Sangat baik \\
\hline & Kualitas soal-soal latihan & & & 2 & 7 & $91,66 \%$ & Sangat baik \\
\hline & III. ASPEK KEBAHASAAN & & & 68 & & $95,44 \%$ & Sangat baik \\
\hline & Kemudahan pemahaman bahasa & & & 2 & 7 & $91,66 \%$ & Sangat baik \\
\hline 11. & Kemudahan memahami pembelajaran & & & 2 & 7 & $100 \%$ & Sangat baik \\
\hline & IV. ASPEK PEMILIHAN GAMBAR & & & 69 & & $95,83 \%$ & Sangat baik \\
\hline & Tampilan & & & & 9 & $100 \%$ & Sangat baik \\
\hline 13. & Ilustrasi & & & 3 & 6 & $100 \%$ & Sangat baik \\
\hline & Jumlah rata-rata & & & 448 & & $95,72 \%$ & Sangat baik \\
\hline
\end{tabular}

Uji coba lapangan menghasilkan data-data yang nantinya akan mengukur kelayakan dari produk yang dikembangkan serta untuk mengetahui manfaat produk tersebut bagi pemakainya. Hasil evaluasi uji coba lapangan terbatas dapat dilihat pada tabel 7.

Tabel 7. Data Hasil Angket Uji Coba Lapangan Terbatas

\begin{tabular}{|c|c|c|c|c|c|c|}
\hline \multirow[t]{2}{*}{ No } & \multirow[t]{2}{*}{ Indikator/ Pernyataan } & \multicolumn{3}{|c|}{ Responden } & \multirow{2}{*}{$\begin{array}{l}\text { Rata- } \\
\text { rata }\end{array}$} & \multirow[t]{2}{*}{ Kriteria } \\
\hline & & 1 & 23 & 4 & & \\
\hline & I. ASPEK KELAYAKAN ISI & & 452 & & $94,16 \%$ & Sangat baik \\
\hline 1. & Kesesuaian materi & & 4 & 20 & $97,22 \%$ & Sangat baik \\
\hline 2. & $\begin{array}{l}\text { Kejelasan petunjuk dalam } \\
\text { pembelajaran }\end{array}$ & & 6 & 18 & $100 \%$ & Sangat baik \\
\hline 3. & Kemudahan memahami kalimat teks & & 10 & 14 & $83,33 \%$ & Sangat baik \\
\hline 4. & Ketepatan urutam materi & & 2 & 22 & $91,66 \%$ & Sangat baik \\
\hline 5. & $\begin{array}{l}\text { Keterlibatan dan peran siswa dalam } \\
\text { aktifitas belajar }\end{array}$ & & 6 & 18 & $91,66 \%$ & Sangat baik \\
\hline & $\begin{array}{l}\text { II. ASPEK KELAYAKAN } \\
\text { PENYAJIAN }\end{array}$ & & 361 & & $94,01 \%$ & Sangat baik \\
\hline & Kualitas gambar & & 2 & 22 & $100 \%$ & Sangat baik \\
\hline & Komposisi warna & & 1 & 23 & $83,33 \%$ & Sangat baik \\
\hline & Kemenarikan isi cerita & & 18 & 6 & $75,00 \%$ & Sangat baik \\
\hline & Kualitas soal-soal latihan & & 2 & 22 & $91,66 \%$ & Sangat baik \\
\hline & III. ASPEK KEBAHASAAN & & 186 & & $96,87 \%$ & Sangat baik \\
\hline 10. & Kemudahan pemahaman bahasa & & 4 & 20 & $91,66 \%$ & Sangat baik \\
\hline & Kemudahan memahami pembelajaran & & 2 & 22 & $100 \%$ & Sangat baik \\
\hline & IV. ASPEK PEMILIHAN GAMBAR & & 188 & & $97,91 \%$ & Sangat baik \\
\hline 12. & Tampilan & & & 24 & $100 \%$ & Sangat baik \\
\hline 13. & Ilustrasi & & 4 & 20 & $100 \%$ & Sangat baik \\
\hline & Jumlah rata-rata & & 1187 & & $95,10 \%$ & Sangat baik \\
\hline
\end{tabular}


Hasil rangkuman persentase skor total dari hasil validasi ahli dan uji coba bahan ajar dapat dilihat pada tabel 8 dibawah ini.

Tabel 8. Persentase Skor Total Hasil Penilaian Validasi Ahli dan Uji Coba Bahan Ajar

\begin{tabular}{cccc}
\hline No & \multicolumn{1}{c}{ Responden } & Persentase Rata-rata & Kriteria \\
\hline 1 & Ahli materi pembelajaran & $88,23 \%$ & Sangat baik \\
\hline 2 & Ahli desain pembelajaran & $82,89 \%$ & Sangat baik \\
\hline 3 & Ahli media pembelajaran & $83,55 \%$ & Sangat baik \\
\hline 4 & Uji coba perorangan & $92,94 \%$ & Sangat baik \\
\hline 5 & Uji coba kelompok kecil & $95,72 \%$ & Sangat baik \\
\hline 6 & Uji coba lapangan terbatas & $95,10 \%$ & Sangat baik \\
\hline & Rata-rata & $89,73 \%$ & Sangat baik \\
\hline
\end{tabular}

\section{Pembahasan}

Produk pengembangan bahan ajar kewirausahaan berbasis kontekstual merupakan materi pembelajaran yang telah dikembangkan dengan memperhatikan aspek pembelajaran. Penelitian dan pengembangan ini produk yang dilakukan ini diarahkan untuk menghasilkan suatu produk berupa bahan ajar kewirausahaan berbasis kontekstual untuk siswa yang digunakan untuk meningkatkan proses pembelajaran maupun kompetensi siswa. Oleh sebab itu proses penelitian dilakukan

dan diawali dengan, (1) studi pendahuluan, (2) mendesain media pembelajaran, (3) melakukan validasi produk dan melakukan revisi dan penyempurnaan berdasarkan analisis data dari ahli materi, dan (4) ahli desain pembelajaran yang dilanjutkan dengan uji coba perorangan, uji coba kelompok kecil, dan uji coba lapangan terbatas sehingga dihasilkan bahan ajar yang layak digunakan sesuai dengan karakteristik bidang studi dan siswa sebagai pengguna.

Aspek yang direvisi dan disempurnakan berdasarkan analisis data dan uji coba serta masukan dari ahli materi, ahli desain pembelajaran, dan ahli media pembelajaran dan siswa selaku pengguna media pembelajaran berupa bahan ajar berbasis kontekstual ini, bertujuan untuk menggali aspek yang lazim dalam proses pengembangan suatu produk. Aspek-aspek bahan ajar memiliki nilai rata-rata sangat baik. Adapun variabel bahan ajar yang dinilai meliputi kelayakan isi, penyajian, kebahasaan dan kegrafikan.

Hasil revisi selanjutnya diuji cobakan kepada siswa melalui uji coba perorangan, kelompok kecil, dan lapangan terbatas. Uji coba ini diharapkan mendapatkan umpan balik untuk menghasilkan bahan ajar yang layak digunakan sesuai dengan karakteristik siswa sebagai pengguna. Hal ini sejalan dengan pendapat Borg and Gall (1983:772) pada buku Education Research an Education yang mengemukakan bahwa penelitian pengembangan adalah penelitian yang berorientasi untuk mengembangkan dan memvalidasi produkproduk yang digunakan dalam pendidikan. Setelah melakukan serangakaian uji coba dan mendapatkan umpan balik dari siswa sebagai pengguna, maka dilakukan revisi berdasarkan saran dan

masukan para ahli untuk menghasilkan bahan ajar yang layak digunakan. Dari data validasi secara keseluruhan responden diperoleh nilai dengan kriteria sangat baik dan layak digunakan dalam pembelajaran.

\section{PENUTUP}

Berdasarkan rumusan, tujuan, hasil dan pembahasan penelitian pengembangan bahan ajar kewirausahaan berbasis kontekstual yang dikemukakan sebelumnya maka dapat disimpulkan bahwa bahan ajar kewirausahaan yang dihasilkan layak untuk digunakan. Kelayakan ini diperoleh dari hasil penilaian validasi ahli dan uji coba. Adapun hasil penilaian tersebut adalah sebagai berikut:

1. Hasil validasi dari ahli materi terhadap bahan ajar kewirausahaan berbasis kontekstual yang dikembangkan menunjukkan bahwa: (1) kualitas aspek kelayakan isi memperoleh nilai sebesar $87,50 \%$, (2) kualitas aspek kelayakan penyajian memperoleh nilai sebesar $89,58 \%$, (3) kualitas aspek kebahasaan memperoleh nilai sebesar 91,66\%, dan (4) kualitas aspek kegrafikan memperoleh nilai sebesar 91,66\%. Dengan demikian persentase skor total penilaian ahli materi terhadap bahan ajar kewirausahaan berbasis kontekstual adalah 88,23\% dan secara keseluruhan termasuk kategori "sangat baik". 
2. Hasil validasi dari desain pembelajaran terhadap bahan ajar kewirausahaan berbasis kontekstual yang dikembangkan menunjukkan bahwa: (1) kualitas aspek kelayakan isi memperoleh nilai sebesar $87,50 \%$, (2) kualitas aspek kelayakan penyajian memperoleh nilai sebesar $78,75 \%$, dan (3) kualitas aspek kegrafikan memperoleh nilai sebesar $87,50 \%$. Dengan demikian persentase skor total penilaian ahli desain terhadap bahan ajar kewirausahaan berbasis kontekstual adalah $82,89 \%$ dan secara keseluruhan termasuk kategori "sangat baik".

3. Hasil validasi dari ahli media pembelajaran terhadap bahan ajar kewirausahaan berbasis kontekstual yang dikembangkan menunjukkan bahwa: (1) kualitas aspek kelayakan isi memperoleh nilai sebesar $91,60 \%$, (2) kualitas aspek kelayakan penyajian memperoleh nilai sebesar $85,00 \%$, dan (3) kualitas aspek kegrafikan memperoleh nilai sebesar $77,08 \%$. Dengan demikian persentase skor total penilaian ahli materi terhadap bahan ajar kewirausahaan berbasis kontekstual adalah $83,55 \%$ dan secara keseluruhan termasuk kategori "sangat baik".

4. Menurut tanggapan siswa pada uji coba perorangan dinyatakan bahwa bahan ajar termasuk kategori "sangat baik" dengan rata-rata persentase $92,94 \%$ dimana aspek kelayakan isi memperoleh persentase sebesar 93,33\%, kelayakan penyajian memperoleh persentase sebesar $87,50 \%$, dan kelayakan kebahasaan memperoleh persentase sebesar 95,83\%, dan pemilihan gambar memperoleh persentase sebesar $100 \%$.

5. Menurut tanggapan siswa pada uji coba kelompok kecil dinyatakan bahwa bahan ajar termasuk kategori "sangat baik" dengan rata-rata persentase $95,72 \%$ dimana aspek kelayakan isi memperoleh persentase sebesar $94,44 \%$, kelayakan penyajian memperoleh persentase sebesar $97,91 \%$, dan kelayakan kebahasaan memperoleh persentase sebesar $95,44 \%$, dan pemilihan gambar memperoleh persentase sebesar $95,83 \%$.

6. Menurut tanggapan siswa pada uji coba lapangan terbatas dinyatakan bahwa bahan ajar termasuk kategori "sangat baik" dengan rata-rata persentase $92,94 \%$ dimana aspek kelayakan isi memperoleh persentase sebesar 94,16\%, kelayakan penyajian memperoleh persentase sebesar $94,01 \%$, dan kelayakan kebahasaan memperoleh persentase sebesar $96,87 \%$, dan pemilihan gambar memperoleh persentase sebesar $97,91 \%$.

\section{DAFTAR PUSTAKA}

Anonim. (2000). Peraturan Pemerintah Nomor 29 Tahun 1990 Tentang Pendidikan Menengah. Jakarta. Depdiknas.

Belawati, Tian. (2003). Pengembangan Bahan Ajar. Jakarta:Divapress.

Daryanto. (2010). Evaluasi Pendidikan. Jakarta. Rineka Cipta.

Dick, Walter, Lou Carey, and James O Carey. (2005). The Systematic Design of Instruction 6 ed, Boston. Pearson.

Depdiknas. (2006). Permendiknas No. 22 Tahun 2006 Tantang Standar Isi. Jakarta. Depdiknas.

Farnk, Andrea I. (2005). "Developing Entrepreneurship Skills in the Context of Higher Education". Journal International Developing Entrepreneurship Skills.

Hudson dan Whisler. (2016). "Contextual Teaching and Learning for Practitioners". Systemics, Cybernetics And Informatics Volume 6 Number 4 ISSN: 1690-4524.

Milfayetti, Sri, dkk. (2012). Psikologi Pendidikan. Medan. Penerbit Universitas Negeri Medan

Pannen, P. Purwanto. (2001). Penulisan Bahan Ajar. Jakarta: Dirjen Dikti Depdiknas

Prastowo, Andi. (2011). Metode Penelitian Kualitatif dalam Perspektif Rancangan Penelitian. Jogjakarta: Ar-Ruzz Media.

Sagala, Saiful. (2005). Konsep dan Makna Pembelajaran. Bandung. CV. Alvabeta.

Sari. (2010). Hubungan Hasil Belajar Kewirausahaan Dengan Motivasi Berwiraswasta Siswa di SMK Dua Mei Ciputat. Skripsi Program Strata Satu (SI) Fakultas Ilmu Tarbiyah dan Keguruan Universitas Islam Negeri Syarif Hidayatullah Jakarta.

Sudrajat, Akhmad. (2008). Pengertian Pendekatan, Strategi, Metode, Teknik dan Model Pembelajaran. Bandung : Sinar Baru Algensindo.

Sukiman. (2011). Penelitian Tindakan Kelas untuk Guru Pembimbing. Yogyakarta. Paramitra Publishing.

Sungkono, dkk. (2003). Pengembangan Bahan Ajar. Yogyakarta. FIP UNY. 
Jurnal TIK dalam Pendidikan, Vol. 8 No. 1 Juni 2021, p-ISSN: 2355-4983, e-ISSN: 2407-7488

Widodo, C. dan Jasmadi. (2008). Buku Panduan Menyusun Bahan Ajar. Jakarta : PT Elex Media Komputindo.

Borg W.R. \& Gall.M.D. (1983). Educational Research: An Introduction. London: Longman Inc. 